\title{
Factors that Influence Information Systems Undergraduates to Pursue IT Certification
}

\author{
D. Scott Hunsinger \\ Appalachian State University, \\ Boone, NC, USA
}

hunsingerds@appstate.edu

\author{
Michael A. Smith \\ High Point University, \\ High Point, NC, USA
}

msmith@highpoint.edu

\section{Executive Summary}

We identify factors that influence the intent of undergraduate information systems majors to pursue IT certification. Previous research has revealed that IT/IS hiring managers may use certification as a job requirement or to differentiate between job candidates with similar levels of education and experience. As well, salary surveys have shown that certified employees often make more money and bonuses than non-certified workers. If teachers and trainers wanted better to influence students' decisions about IT certification when the job market signals that being certified gives an applicant an advantage in being hired, where would they begin?

We used interview and survey data and a well-known theory, the Theory of Planned Behavior (TPB), to identify the factors that influence students' intentions to earn an IT certification. The TPB proposes that three constructs, 1) Attitude, 2) Subjective Norms, and 3) Perceived Behavioral Control, are significant in predicting Behavioral Intention, which in turn predicts behavior. Recent research suggests that Attitude can be predicted using two more constructs: Affect (emotion) and Cognition (outcome beliefs). We conducted interviews with undergraduates to identify outcome beliefs. We also identified referent groups for Subjective Norms and Self-Efficacy beliefs for measuring Perceived Behavioral Control. We used measures validated in other studies to measure Behavioral Intention, Attitude, and Affect. We targeted accessible undergraduate information systems students at two universities in the Southeastern US. Two hundred fifty-two (252) students were asked to participate in the study; 120 students completed our Web-based survey, a response rate of $47.6 \%$. We used hierarchical multiple regression to analyze the survey responses. In the first hierarchical regression analysis, all three TPB constructs were significant in predicting Behavioral Intention. However, Attitude was far more influential than either Subjective Norms or Perceived Behavioral Control. In the second analysis, we found that Affect influenced Attitude far more than did Cognition. The adjusted $\mathrm{R}^{2}$ of the model was .513.

Responses to the on-line questionnaire reflect a consistently positive view of the outcomes of pursuing IT certification. However, about $1 / 3$ of respondents rated their reactions to statements ask-

Material published as part of this publication, either on-line or in print, is copyrighted by the Informing Science Institute. Permission to make digital or paper copy of part or all of these works for personal or classroom use is granted without fee provided that the copies are not made or distributed for profit or commercial advantage AND that copies 1) bear this notice in full and 2) give the full citation on the first page. It is permissible to abstract these works so long as credit is given. To copy in all other cases or to republish or to post on a server or to redistribute to lists requires specific permission and payment of a fee. Contact Publisher@,InformingScience.org to request redistribution permission. ing them whether they believe IT managers and hiring managers think they should pursue an IT certification as "neutral". This was surprising given that these managers are ultimately responsible for delivering the benefits of IT certification to employees. As well, little more than half the respondents indicated that they had the money and resources to pursue IT certification. Student comments suggested that lack of 
time was an important impediment for them, an item that did not emerge from our initial interviews. Students also suggested that teachers provide more information about IT certification to students so they are better informed for the job market after graduation.

Keywords: Certification, theory of planned behavior, affect, employment, undergraduates, information systems, social closure

\section{Introduction}

"I am a rising senior who is currently trying to obtain an entry-level IT job and have been turned down because I do not have any certifications."

Methods of social closure (Weber, 1922/1978), such as voluntary certification, licensing, and credentialing, are used in professions, such as law, accounting, education, airplane piloting and engineering, to signal quality, focus demand, and enhance rewards for professionals. The IT field possesses no universal means of social closure. However, voluntary certification has emerged as a method of ensuring and signaling the skill level of IT workers, sometimes serving as a substitute for experience and/or education (Childs, 2002). Certified employees often make more money and bonuses than non-certified workers (Gabelhouse, 2002; McCarthy, 2002; Shaffhauser, 2002; Sosbe, 2001; Tittel, 2001) and certification helps them earn promotions and raises (Dohner, 2001; Domingo, 2007; Gabelhouse, 2001).

IT certification is popular and important for job-seekers. It is estimated that over 1,000 IT certifications are available (Rowe, 2003). Approximately 6.5 million people in the U.S. hold a computer certification; that number may exceed 20 million by 2010 . Industry analysts estimated the size of the certification training market in North America at $\$ 500$ to $\$ 600$ million in 2000, climbing as much as 20 percent per year for the foreseeable future (Tittel, 2001). Worldwide spending in IT certification was estimated to reach $\$ 4$ billion in 2003 according to an IDC report (Flynn, 2002). A study of hiring managers from approximately 700 companies both inside and outside the IT industry found that "IT companies viewed certifications at least as important as a bachelor's degree while non-IT companies placed certifications slightly below a bachelor's degree in importance" (ITAA, 2001). Another study found that over half the CIOs surveyed "would hire a person with a certification, even if they had no work experience. Some even said they would not hire anyone without a certification" (Childs, 2002).

The popularity of IT certifications suggests that many IT professionals believe managers use it as a selection tool when hiring. "Human resource managers have typically used IT certifications as an indicator of an applicant's base-line suitability for a specific IT related position. Certifications act as a signal to hiring managers that a job candidate has achieved a level of knowledge and skill necessary to perform in a particular IT job role" (Randall \& Zirkle, 2005).

Employers are increasingly turning to certifications as a way to make sure that prospective employees possess the necessary skills (Al-Rawi, Bouslama, \& Lansari, 2006). Employers often desire and may even require certain computer certifications as a condition of employment (Hitchcock, 2007). Employers often assume that certified employees are better able to manage the organization's IS resources (Cegielski, 2004). For example, "Many employers assume a certified network professional is better able to manage networked resources than is a non-certified counterpart" (Cegielski, Rebman, \& Reithel, 2003).

A survey of hiring managers (Hunsinger \& Smith, 2005) revealed that they use certification to screen applicants, to differentiate between otherwise equally qualified applicants, to qualify for service-agreement discounts and warranty protection, and to validate their employees' qualifications to their own customers, among other reasons. The usefulness of certification may depend 
on the field within IS and the level of the position (entry vs. management.) Hiring managers use IT certification in addition to and sometimes in place of academic qualifications.

Depending on the position sought, there are often clear advantages to possessing a certification. Zeng (2004) notes that many students in CIS and CS programs want to earn both certification and a degree in order to meet increasing demands from industry. Randall and Zirkle (2005) stated, "A student that has obtained a certification as an addition to a post-secondary education has a strong theoretical foundation to build on, an increased marketability, and better chances for long term career success." Students entering the workforce are more marketable when they possess IT certifications along with their education (Al-Rawi, Lansari, \& Bouslama, 2005). Industry certifications give individuals a more complete and diverse set of credentials to enter the job market (Hitchcock, 2005). Brookshire (2000) notes that IT certifications are very important, as students use the skills associated with them to get better jobs. Students benefit financially from holding IT certification because "employers relate certification to evidence of skill and reward persons with those skills" (Ray \& McCoy, 2000).

However, some IS students choose not to pursue certifications.

This paper addresses the research question: What factors affect the decision of undergraduate information systems majors to pursue IT certification? We use the Theory of Planned Behavior with the addition of Affect and Cognition constructs to investigate and analyze the salient beliefs of students in several information systems classes and to identify the factors that most influence their decisions to pursue IT certification in the next twelve months. Participants in the survey included Computer Information Systems (CIS), Management Information Systems (MIS), Information Security and Privacy (ISP) and Computer Science (CS). All respondents were enrolled in undergraduate courses offered in a Business program. The jobs most commonly sought by the participants include: Network or Systems Administrator, Systems Analyst, Security Analyst, Business Programmer, Software Developer, IS Auditor, and Project Manager.

Teachers and trainers will benefit from knowing how better to influence students' decisions about IT certification when the job market signals that being certified gives an applicant an advantage in being hired. Designers and sponsors of certifications, including IT vendors, as well as thirdparty training and testing centers, who have an interest in increasing enrollments in their programs, will benefit from knowing what factors influence the decisions of undergraduates to pursue certifications.

\section{Predicting Intent and Behavior}

\section{The Theory of Planned Behavior}

The Theory of Planned Behavior (TPB) (Ajzen, 1991) has been used in multiple fields to predict intention and behavior (Ajzen, 2001; Armitage \& Conner, 2000; Ingram, Cope, Harju, \& Wuensch, 2000; Sutton, 1998), including intention related to information technology use (Chau \& Hu, 2001; F. D. Davis, 1989; Harrison, Mykytyn, \& Riemenschneider, 1997).

In this study, the behavior investigated is that of pursuing IT certification within the next twelve months.

The TPB, illustrated in Figure 1, expands the theory of reasoned action (TRA) (Fishbein \& Ajzen, 1975) to deal with behaviors under incomplete volitional control by including an additional construct: Perceived Behavioral Control. Performance of behaviors under incomplete volitional control may depend on availability of opportunities and resources, including time, money, skills, and cooperation of others (Ajzen, 1991). 


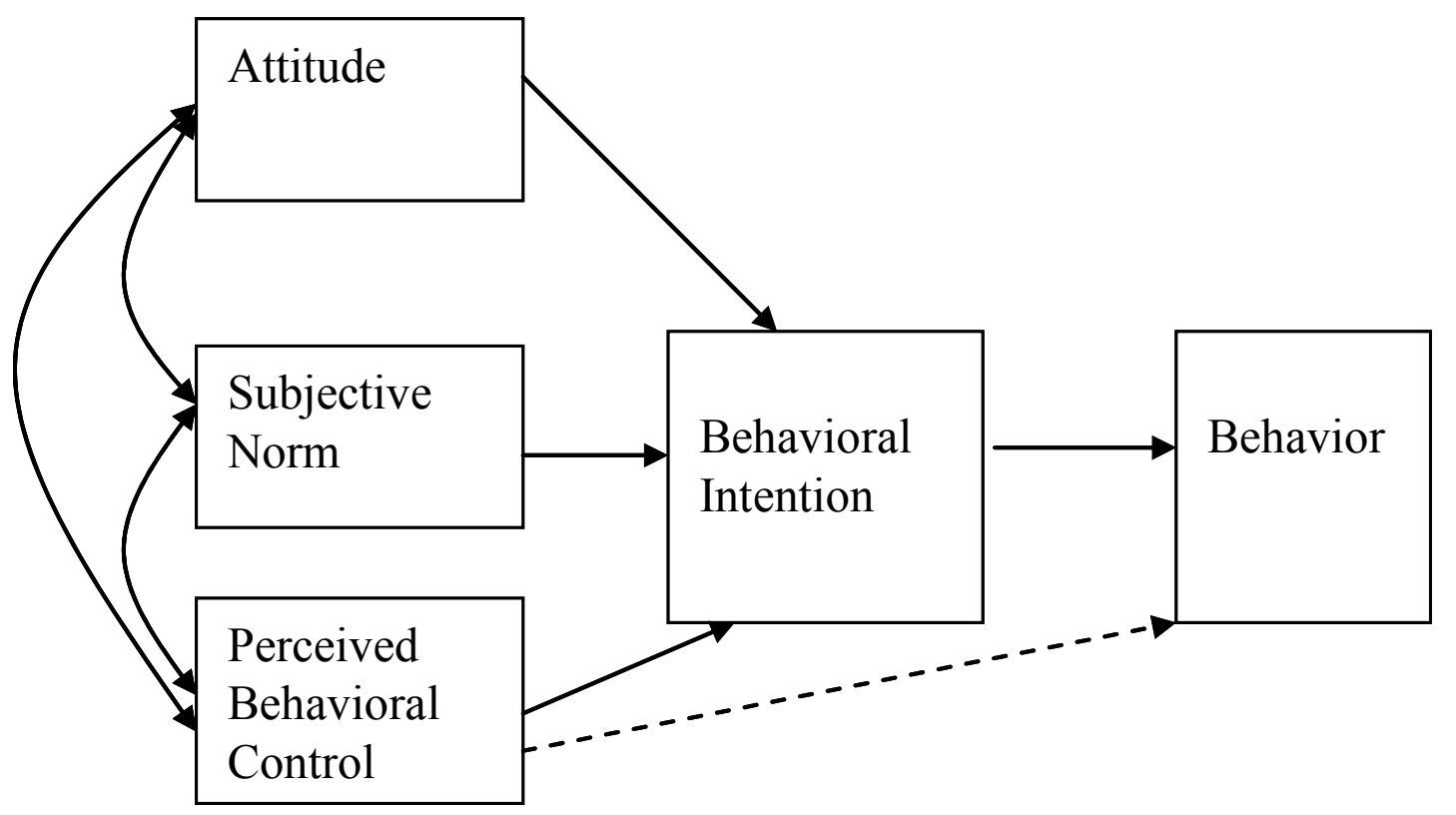

Figure 1: Theory of Planned Behavior (after Ajzen, 1991)

The TPB predicts intention using three constructs:

- Attitude toward the behavior is the degree to which a person has a favorable or unfavorable evaluation of the behavior in question (Ajzen, 1991).

- Subjective Norm refers to the person's perception of the social pressures to perform or not perform the behavior (Ajzen, 1991). These social pressures arise from members of referent groups (those groups that influence their decisions).

- Perceived Behavioral Control refers to the perceived ease or difficulty of performing the behavior (Ajzen, 1991). This construct is derived from Bandura's (1977) concept of selfefficacy - "the conviction that one can successfully execute (a given) behavior" (Eagly \& Chaiken, 1993). In previous studies, measures of Perceived Behavioral Control have often been found to improve prediction of behavior above and beyond attitude and subjective norm, especially when volitional control is not high (Ajzen \& Fishbein, 2005).

The relative influence of each construct differs with the behavior being examined as well as with the group being studied. Occasionally, a construct is not found to be a significant influence.

\section{Affect and Cognition as Predictors of Attitude}

Attitude may be better explained if we consider it in terms of two aspects: Affective, or emotional, and cognitive, or outcome beliefs (Ajzen, 2001; Lavine, Thomsen, Zanna, \& Borgida, 1998; Manstead \& Parker, 1995; J. D. Morris, Wood, Geason, \& Kim, 2002; Verplanken, Hofsee, \& Janssen, 1998). Affect deals with how a person feels about performing a particular behavior; it is emotion-based. Cognition deals with what a person thinks about performing a particular behavior; it is belief-based (Verplanken et al., 1998).

It is important to consider the two aspects of attitude because individuals differ in the extent to which they rely upon affective and cognitive information in structuring their attitudes. "Thinkers" (cognition-based) are more likely to base their attitude toward capital punishment upon cog- 
nitive information, and "feelers" (affect-based) are more inclined to base their attitude toward capital punishment on their emotions (Haddock \& Zanna, 1998). "The two components also take on different degrees of importance for different attitude objects" (Ajzen, 2001). This study separates affective evaluations from outcome beliefs as suggested by Manstead and Parker (1995).

Previous studies on Affect and Cognition have found that they are positively related to attitude (Lavine et al., 1998). For example, in the case of the use of IT certification in the hiring process, results of a previous study of managers (Hunsinger \& Smith, 2005) suggest that both Affect and Cognition are positively related to attitude.

\section{Hypotheses}

Figure 2 illustrates the model and the hypotheses. The TPB holds that a person's intention to perform the behavior in question is stronger when Attitude and Subjective Norm are more favorable and Perceived Behavioral Control is greater (L. E. Davis, Ajzen, Saunders, \& Williams, 2002).

- Hypothesis 1: Attitude toward the behavior is significantly and positively related to intent to pursue IT certification within the next twelve months.

- Hypothesis 2: Subjective Norm is significantly and positively related to intent to pursue IT certification within the next twelve months.

- Hypothesis 3: Perceived Behavioral Control is significantly and positively related to intent to pursue IT certification within the next twelve months.

- Hypothesis 4: Cognition is significantly and positively related to Attitude regarding pursuing IT certification within the next twelve months.

- Hypothesis 5: Affect is significantly and positively related to Attitude regarding pursuing IT certification within the next twelve months.

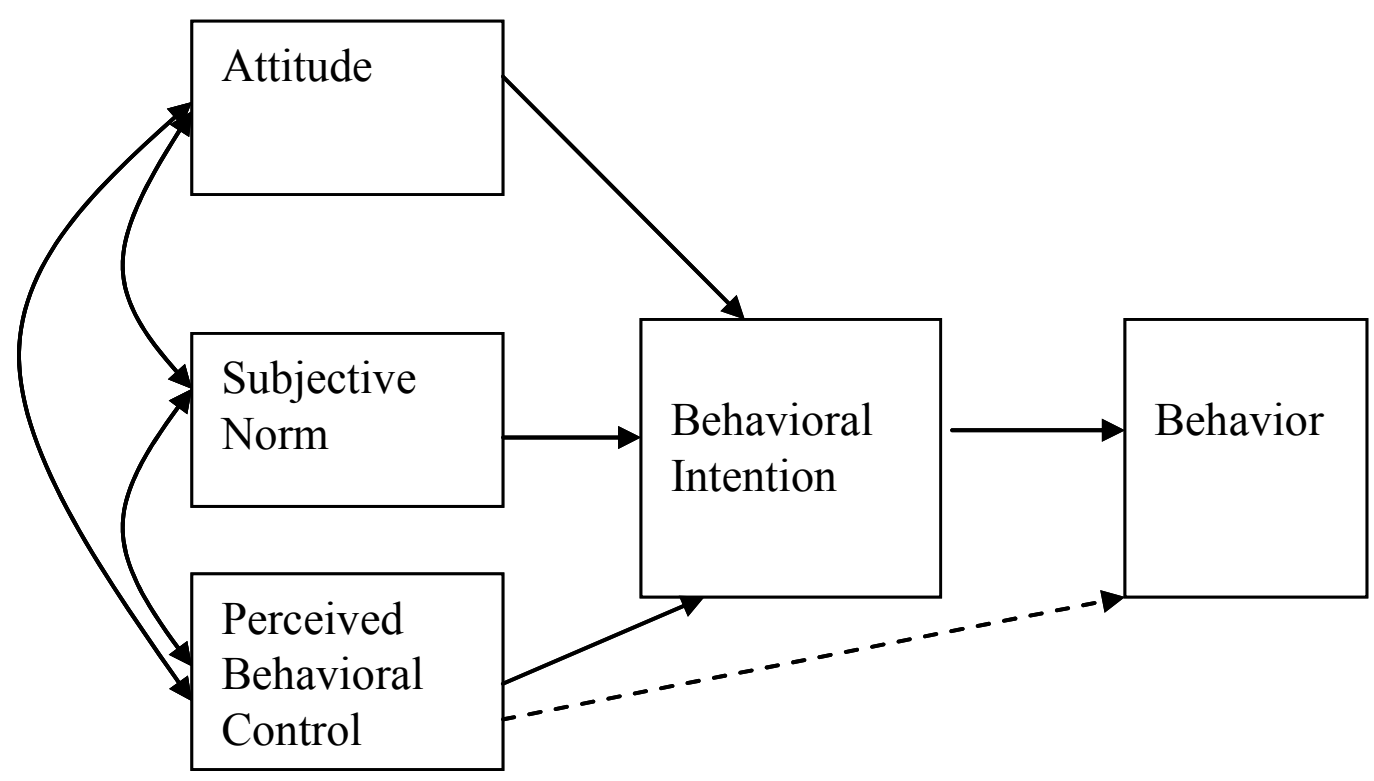

Figure 2: Model of IS Students' Intention to Earn IT Certification 


\section{Research Method}

We began our research on students' perceptions of IT certification by interviewing students. We randomly selected fifteen CIS/MIS majors and asked each of them questions concerning their thoughts about IT certification. Since different beliefs and referent groups may apply to different behaviors and different research populations, we based some of our measures on what the students stated in these interviews. We used the theory of planned behavior (Ajzen, 1991) and Ajzen's recommendations for constructing a theory of planned behavior questionnaire (Ajzen, 2002) to guide our interview questions.

Using structured interviews, we investigated students' beliefs, thoughts, feelings, and attitudes about IT certification. We asked students to identify referent groups (such as parents, professors, or friends) who influence their decisions. In addition, students were asked about self-efficacy factors (such as lack of knowledge or money) that might prevent them from pursuing an IT certification. Ajzen (2002) notes that pilot work, often done through preliminary interviews, is required to identify accessible behavioral, normative, and control beliefs such as referent groups.

Next, based on interview data, we created an online survey using SurveyMonkey (www.surveymonkey.com). As recommended by Ajzen (1991), we integrated the findings from the interviews with the theory of planned behavior constructs (Attitude, Subjective Norm, and Perceived Behavioral Control) to begin empirically analyzing students' intentions to pursue an IT certification. Since some researchers, including Ajzen himself (2001), have recognized that other variables may be necessary under some circumstances to better predict intention, we included two additional constructs, Affect and Cognition.

To verify the temporal stability of our survey instrument, we conducted a pilot study. We asked students in two of our CIS/MIS courses to complete the questionnaire on two occasions approximately three weeks apart. Twenty-seven students completed the questionnaire on both occasions. This sample size is similar to those used in previous pilots reported in Ajzen and Fishbein (1980, pp. 105, 120). We found that the instrument remained consistent over time. (More details are provided later about the test-retest reliability of the constructs). We asked students to provide suggestions concerning the questionnaire length, sequence of questions, wording issues, or other comments and refined the original questionnaire based on that feedback. The students that participated in the pilot study did not participate in the main study.

\section{Measures}

We used items validated in other research to measure three constructs: Behavioral Intention, Attitude, and Affect. Based on recommendations when applying the Theory of Planned Behavior (Ajzen, 1991, 2002), other items were measured using items we developed from interviews with students.

\section{Behavioral intention}

Three previously validated items, "I plan to earn," "I intend to pursue," and "To the extent possible, I plan to pursue," were used to measure each respondent's intention to earn IT certification (Ajzen, 1991; Ajzen \& Fishbein, 1980). Respondents rated each item for the statement, “_ an IT certification in the next twelve months" on a seven-point bi-polar scale ranging from -3 (Strongly Disagree) to +3 (Strongly Agree). Cronbach's alpha for Behavioral Intention was .94, exceeding the recommended cutoff value of .70 (Santos, 1999). Pearson's $r$ for test-retest reliability, $r=.64$, was acceptable (see Nunnally, 1978). 


\section{Attitude}

We computed a measure of Attitude toward intention to pursue certification using statements validated in previous TRA and TPB studies that were found to exhibit high internal consistency (Ajzen, 1991, 2001; Sheppard, Hartwick, \& Warshaw, 1988). To gauge students' attitudes concerning certification, the following seven-point scales were used to rate the statement, "For me, pursuing an IT certification in the next twelve months is a idea": Very good / Very bad; Very positive / Very negative; Very helpful / Very unhelpful. Cronbach's alpha for Attitude was .92, and Pearson's $r$ for test-retest reliability was .66.

\section{Normative beliefs and motivation to comply (Subjective norm)}

We identified referent groups in interviews with students. The following referent groups were deemed important by at least half of the students in the interviews: 1) IT managers, 2) My professors, 3) Hiring managers, 4) My advisors, 5) My parents, and 6) The general public.

To measure normative beliefs, participants rated their agreement or disagreement with statements about the views of each of the referent groups using a seven-point scale ranging from Strongly Agree (+3) to Strongly Disagree (-3). Students rated each referent group on a seven-point scale for the statement: “" think I should pursue an IT certification within the next twelve months."

We also asked respondents to rate their motivation to comply with the opinions of each referent group on a seven-point scale ranging from Very Undesirable (1) to Very Desirable (7). Students rated each referent group for the statement, "Generally speaking, I do what think I should do."

Following the practice of other studies based on the Theory of Planned Behavior (Ajzen, 1991), we calculated a measure of Subjective Norm by multiplying each normative belief by the corresponding motivation to comply and summing the products.

Pearson's $r$ for test-retest reliability, $r=.56$, was acceptable (see Nunnally, 1978). For theoretical reasons, it is inappropriate to compute Cronbach's alpha on the belief composites, as we cannot assume that the beliefs are internally consistent (Ajzen, 2002).

\section{Perceived control and degree of facilitation (Perceived behavioral control)}

We used several statements generated from the interviews to measure the strength of the respon-

dent's perceived control beliefs; related statements were used to compute the perceived degree of facilitation of these beliefs. The following perceived control beliefs were mentioned by at least half of the students in interviews: Having the 1) Learning ability, 2) Knowledge, 3) Skills, and 4) Money and resources.

Perceived control beliefs were rated on a scale ranging from Strongly Agree ( +3$)$ to Strongly Disagree (-3). Students rated each control belief for the statement, "I to earn an IT certification within the next twelve months."

Perceived degree of facilitation was rated using values from 1 (Much Easier) to 7 (Much More Difficult). Students rated their perceived degree of facilitation for each referent group for the statement, "For me, having the to pursue an IT certification would make it [much easier---much more difficult] to earn an IT certification in the next twelve months."

We calculated Perceived Behavioral Control (Ajzen, 1991) by multiplying each control belief by the corresponding perceived degree of facilitation and adding the products. 
Pearson's $r$ for test-retest reliability, $r=.54$, indicates sufficient internal reliability (Nunnally, 1978). As was the case for subjective norm, it is inappropriate to compute Cronbach's alpha on the belief composites, as we cannot assume that the beliefs are internally consistent (Ajzen, 2002).

\section{Outcome beliefs and evaluations (Cognition)}

Outcome belief measures were based upon input from interviews with undergraduate students concerning IT certification. Outcome beliefs mentioned by at least fifty percent of the interviewees were included in the survey instrument. The following nine beliefs concerning certification are: 1) Would make me more valuable to a company, 2) Would increase my marketability to potential employers, 3) Would increase my helpfulness to a company, 4) Would increase my qualifications for a job, 5) Would give me an advantage over other job candidates who do not hold an IT certification, 6) Would help me to earn more respect, 7) Would differentiate me from other job candidates applying for a position, 8) Would help me make more money than a similar job candidate who does not hold an IT certification, and 9) Would increase my likelihood of getting hired by an employer.

We asked survey respondents to rate these nine outcome beliefs on a seven-point scale ranging from Strongly Disagree (-3) to Strongly Agree $(+3)$. Students rated each belief pertaining to the statement, "Earning an IT certification within the next twelve months...."

Participants also indicated the outcome evaluation for each statement on a scale ranging from Very Undesirable (1) to Very Desirable (7). Students rated each of the outcome beliefs using this seven-point scale.

We computed the Cognition measure by multiplying the likelihood rating for each outcome by its outcome evaluation and summing the products.

Pearson's $r$ for test-retest reliability $(r=.75)$ was acceptable.

\section{Affect}

We computed Affect using previously validated measures (Crites, Fabrigar, \& Petty, 1994; Simons \& Carey, 1998). The four Affect measures concerning certification are: 1) Love, 2) Be proud, 3) Be excited, and 4) Be happy. Participants indicated responses on a scale ranging from 1 (Strongly Disagree) to 5 (Strongly Agree) for each Affect measure for the statement, "I would Affect was .93. pursuing an IT certification in the next twelve months." Cronbach's alpha for

Using Cronbach's alpha or test-retest reliability, we found that all constructs were sufficiently reliable. The constructs using Pearson's $r$ have moderate to strong test-retest reliability (Pearson's $r$ values in the range $.54-.75)$ (Nunnally, 1978).

\section{Population and Sample}

The population of interest for this study is undergraduate students of Information Systems (IS) in the United States. The population targeted in this study was undergraduate students in Information Systems courses at two universities in the Southeastern United States. We did not ask students to indicate their class; however, since most freshmen and sophomores at these universities do not formally declare their major until they are admitted to the College of Business, we believe that most respondents were juniors or seniors.

Burns and Grove (2001) recommend using at least 30 subjects per independent variable in order to ensure that the ratio of subjects to independent variables is substantial. The model contains 
five independent variables (Affect, Cognition, Attitude, Subjective Norm, and Perceived Behavioral Control). The model is tested in two parts:

- Test 1 examines the influence of Attitude, Subjective Norm, and Perceived Behavioral Control on Behavioral Intention. The minimum sample size for Test 1 is 90 .

- Test 2 examines the influence of Cognition and Affect on the Attitude construct. The minimum sample size for test 2 is 60 .

These sample sizes are comparable to those of other small-sample studies that use hierarchical multiple regression and the theory of planned behavior (Christian \& Armitage, 2002; M. G. Morris \& Venkatesh, 2000).

We asked 252 undergraduate students to participate in the study. To entice students to complete the on-line survey, we offered to enter their email addresses into drawings for prizes such as gift certificates and flash drives. Student email addresses were not gathered otherwise, and those gathered were discarded after prizes were awarded. We received 120 completed surveys--a response rate of $47.6 \%$.

Specific majors represented in our survey include Computer Information Systems ( 82 responses 68.3\%), Management Information Systems (10 responses - 8.3\%), Information Security and Privacy $(7$ responses $-5.8 \%)$, Computer Science (13 responses $-10.8 \%)$, and Other ( 8 responses $6.7 \%$ ). Regardless of major, all respondents were enrolled in undergraduate courses offered in a business college or school. Of the respondents, 91 were male $(75.8 \%)$ and 29 were female $(24.2 \%)$.

\section{Verifying Assumptions}

Before analyzing the data, we verified the assumptions of normality, homoscedasticity, linearity, and independence. We tested for normality with a normal probability plot of the residuals. Homoscedasticity was checked using plots of residuals versus predicted values. We used a plot of the observed versus predicted values to test for linearity. Independence of the errors was verified by using the Durbin-Watson statistic. Results of the Durbin-Watson test $(\mathrm{d}=2.02)$ for autocorrelation fall within the range $1.5-2.5$ as recommended by Tabachnick and Fidell (2000).

Using SPSS 14.0, we computed the correlations, illustrated in Table 1, and tolerances for each variable. Using cutoffs of .80 for correlations and .20 for tolerance (Garson, n.d.), we determined that multicollinearity does not present a problem.

Table 1: Correlation Matrix (all correlations are significant at the 0.01 level)

\begin{tabular}{|l|l|l|l|l|l|}
\hline & Attitude & Affect & $\begin{array}{l}\text { Perceived } \\
\text { Behavioral } \\
\text { Control }\end{array}$ & Cognition & $\begin{array}{l}\text { Subjective } \\
\text { Norm }\end{array}$ \\
\hline Intention & .682 & .581 & .498 & .459 & .470 \\
\hline Attitude & & .712 & .509 & .624 & .415 \\
\hline Affect & & & .456 & .694 & .587 \\
\hline $\begin{array}{l}\text { Perceived } \\
\text { Behavioral } \\
\text { Control }\end{array}$ & & & & .478 & .375 \\
\hline Cognition & & & & & \\
\hline
\end{tabular}


Only 18 of the 120 respondents (15\%) held an IT certification at the time of the study. However, over $70 \%$ of the students indicated intent to pursue an IT certification in the next twelve months. The most popular certifications to pursue included Network $+(40 \%), \mathrm{A}+(30.8 \%)$, Security + (24.6\%), Microsoft Certified Professional (23.8\%), and the Cisco Certified Network Associate $(16.9 \%)$. Although most students indicated intent to pursue an IT certification, over $1 / 3(36.1 \%)$ of them considered themselves somewhat or very unfamiliar with the IT certification(s) they planned to pursue.

\section{Results}

\section{Salient Beliefs and Referent Groups}

We captured students' perceptions of outcomes of IT certification through nine statements in our survey that were based on data gathered previously during interviews. When asked about various positive outcomes that could await them as a result of holding an IT certification, for each consequence save one, over $90 \%$ of respondents replied with some measure of agreement (somewhat agree, agree, or strongly agree).

Our survey findings suggest that most students believe that IT certification is worthwhile, that earning an IT certification will help them gain employment, make more money, and become more valuable to a company, among other things. Salient outcome beliefs are illustrated in Table 2.

Table 2: Salient Outcome Beliefs

\begin{tabular}{|l|l|l|l|}
\hline Outcome & $\begin{array}{l}\text { Percent } \\
\text { agreeing }\end{array}$ & $\begin{array}{l}\text { Percent } \\
\text { neutral }\end{array}$ & $\begin{array}{l}\text { Percent } \\
\text { disagreeing }\end{array}$ \\
\hline $\begin{array}{l}\text { Would increase my likelihood of getting hired by an em- } \\
\text { ployer. }\end{array}$ & $97.5 \%$ & $2.5 \%$ & $0.0 \%$ \\
\hline $\begin{array}{l}\text { Would differentiate me from other job candidates applying } \\
\text { for a position. }\end{array}$ & $95.9 \%$ & $4.1 \%$ & $0.0 \%$ \\
\hline Would increase my marketability to potential employers. & $95.8 \%$ & $4.2 \%$ & $0.0 \%$ \\
\hline Would increase my qualifications for a job. & $95.8 \%$ & $2.5 \%$ & $1.7 \%$ \\
\hline $\begin{array}{l}\text { Would give me an advantage over other job candidates who } \\
\text { do not hold an IT certification. }\end{array}$ & $95.0 \%$ & $5.0 \%$ & $0.0 \%$ \\
\hline Would increase my helpfulness to a company. & $92.6 \%$ & $5.0 \%$ & $2.4 \%$ \\
\hline Would make me more valuable to a company. & $92.6 \%$ & $5.8 \%$ & $1.6 \%$ \\
\hline $\begin{array}{l}\text { Would help me to make more money than a similar job can- } \\
\text { didate who does not hold an IT certification. }\end{array}$ & $90.9 \%$ & $7.4 \%$ & $1.6 \%$ \\
\hline Would help me to earn more respect. & $81.0 \%$ & $16.5 \%$ & $2.5 \%$ \\
\hline
\end{tabular}

Students were asked to rate each referent group on a seven-point scale for the statement: “_think I should pursue an IT certification within the next twelve months." As Table 3 illustrates, most respondents believe that IT managers, hiring managers, and their professors believe they should earn an IT certification. However, we were surprised at the number of students who responded "neutral" on most of these measures despite there being so many likely benefits to earning a certification. 
Table 3: Referent Groups

\begin{tabular}{|l|l|l|l|}
\hline Referent Group & $\begin{array}{l}\text { Percent } \\
\text { agreeing }\end{array}$ & $\begin{array}{l}\text { Percent } \\
\text { neutral }\end{array}$ & $\begin{array}{l}\text { Percent } \\
\text { disagreeing }\end{array}$ \\
\hline IT managers & $67.0 \%$ & $31.4 \%$ & $1.6 \%$ \\
\hline My professors & $66.9 \%$ & $28.1 \%$ & $5.0 \%$ \\
\hline Hiring managers & $62.0 \%$ & $34.7 \%$ & $3.3 \%$ \\
\hline My advisors & $47.0 \%$ & $48.8 \%$ & $4.2 \%$ \\
\hline My parents & $46.3 \%$ & $47.9 \%$ & $5.8 \%$ \\
\hline The general public & $35.6 \%$ & $60.3 \%$ & $4.1 \%$ \\
\hline
\end{tabular}

Regarding Self-efficacy beliefs, the overwhelming majority of respondents believed they had the learning ability to earn IT certification, and large majorities believed they had the skills and knowledge. On the other hand, Table 4 illustrates that money emerged as an issue for some. "I would love to pursue an IT certification but I do not have the money right now," commented one respondent. Another wrote, "It would nice for [our] students to receive discounted vouchers to take certification tests, or provide free training materials."

Table 4: Self-efficacy Beliefs

\begin{tabular}{|l|l|l|l|}
\hline Self-efficacy Belief & $\begin{array}{l}\text { Percent } \\
\text { agreeing }\end{array}$ & $\begin{array}{l}\text { Percent } \\
\text { neutral }\end{array}$ & $\begin{array}{l}\text { Percent } \\
\text { disagreeing }\end{array}$ \\
\hline Have the learning ability & $95.1 \%$ & $4.1 \%$ & $0.8 \%$ \\
\hline Have the skills & $82.6 \%$ & $11.6 \%$ & $5.8 \%$ \\
\hline Have the knowledge & $73.6 \%$ & $15.7 \%$ & $10.7 \%$ \\
\hline Have the money and resources & $59.5 \%$ & $19.0 \%$ & $21.5 \%$ \\
\hline
\end{tabular}

\section{Affect and Attitude}

Students expressed positive feelings concerning IT certification in both their quantitative survey responses, illustrated in Table 5, and their comments about certification given at the end of the survey. (The last question of the survey asked, "Please provide any other thoughts you would like to share concerning IT certification.") Thirty of the 120 respondents $(25 \%)$ answered this optional question. Several students stated (Emphases are the authors'.), "I would love to pursue an IT certification...." Respondents also exhibited strong emotions in other comments. "I am excited that you are looking into [certification]...," one person stated. Another student said, "...you should have a passion for [earning certification]."

Table 5: Responses to Statements of Positive Affect

\begin{tabular}{|l|l|}
\hline Statement & $\begin{array}{l}\text { Pct. } \\
\text { agreeing }\end{array}$ \\
\hline I would LOVE pursuing an IT certification... & $68.6 \%$ \\
\hline I would feel PROUD pursuing an IT certification... & $81.0 \%$ \\
\hline I would be EXCITED pursuing an IT certification... & $73.6 \%$ \\
\hline I would be HAPPY pursuing an IT certification... & $76.0 \%$ \\
\hline
\end{tabular}


A majority of the surveyed students possess positive attitudes toward earning an IT certification. One student commented, "It would be extremely helpful to be able to earn an IT certification as part of my [computer] major." Another student mentioned that earning an IT certification "... sounds like a good idea." Table 6 summarizes students' responses to statements concerning their attitudes about earning an IT certification.

Table 6: Positive attitudes towards earning an IT certification

\begin{tabular}{|l|l|}
\hline Statement & Pct. agreeing \\
\hline Pursuing an IT certification is a GOOD idea. & $88.5 \%$ \\
\hline Pursuing an IT certification is a POSITIVE idea. & $89.3 \%$ \\
\hline Pursuing an IT certification is a HELPFUL idea. & $88.5 \%$ \\
\hline
\end{tabular}

\section{Testing the Model}

We used hierarchical multiple regression to analyze the questionnaire responses. This technique has been used in a number of previous studies based on the Theory of Planned Behavior (Chau \& Hu, 2001; F. D. Davis, Bagozzi, \& Warshaw, 1989; Harrison et al., 1997; M. G. Morris \& Venkatesh, 2000; Venkatesh, 2001).

Intention is the dependent variable for the first regression.

Assumptions based on theory and research determine when independent variables should be entered into the model (Stockburger, 1998). As each independent variable (or set of variables) is entered, the change in adjusted $\mathrm{R}^{2}$ is calculated, and we determine whether each change is significantly different from zero (Stockburger, 1998). We follow the suggestion of Ajzen and Madden (1986) regarding order of entry of variables in the TPB, beginning with Attitude, followed by Subjective Norm then Perceived Behavioral Control. Table 7 illustrates the results of the first regression.

Table 7. Hierarchical Regression Analysis using Attitude, Subjective Norm, and Perceived Behavioral Control

\begin{tabular}{|l|l|l|l|l|l|}
\hline \multicolumn{1}{|c|}{ Step } & $\begin{array}{c}\text { Independent Vari- } \\
\text { able(s) }\end{array}$ & Adj. $\mathbf{R}^{\mathbf{2}}$ & $\begin{array}{c}\text { Change in } \\
\text { Adj. } \mathbf{R}^{2}\end{array}$ & $\boldsymbol{\beta}$ & $\mathbf{p}$ \\
\hline 1 & Attitude & .460 & .460 & .682 & $* * *$ \\
\hline 2 & Attitude & .499 & .039 & .588 & $* * *$ \\
& Subjective Norm & & & .226 & $* *$ \\
\hline 3 & Attitude & .513 & .014 & .519 & $* * *$ \\
& Subjective Norm & & & .194 & $* *$ \\
& Perceived Behavioral & & & .161 & $*$ \\
& Control & & & & \\
\hline
\end{tabular}

(Dependent variable $=$ Behavioral Intention $)$

$$
* \mathrm{p}<.05 ; \quad * * \mathrm{p}<.01 ; \quad * * * \mathrm{p}<.001
$$


All three original TPB constructs are significant and, as anticipated, each adds to the predictive value of the model in accord with its order of entry into the model. Overall, the model shows a moderate amount of variance explained for Behavioral Intention (Adj. $\mathrm{R}^{2}=.513$ ).

To examine the influences of Cognition and Affect on Attitude, we performed a second hierarchical regression analysis with Attitude as the dependent variable.

We ran this test twice. During the first, we entered Cognition into the equation as the first independent variable since Affect is not measured explicitly in the TPB. Table 8 illustrates the results of the regression.

Table 8. Hierarchical Regression Analysis using Cognition and Affect

\begin{tabular}{|l|l|l|l|l|l|}
\hline \multicolumn{1}{|c|}{ Step } & \multicolumn{1}{|c|}{$\begin{array}{c}\text { Independent } \\
\text { Variable(s) }\end{array}$} & Adj. $\mathbf{R}^{\mathbf{2}}$ & $\begin{array}{c}\text { Change in } \\
\text { Adj. } \mathbf{R}^{\mathbf{2}}\end{array}$ & $\boldsymbol{\beta}$ & $\mathbf{p}$ \\
\hline 1 & Cognition & .368 & .368 & .611 & $* * *$ \\
\hline 2 & Cognition & .525 & .157 & .227 & $*$ \\
& Affect & & & .554 & $* * *$ \\
\hline
\end{tabular}

(Dependent variable $=$ Attitude)

$* \mathrm{p}<.05 ; \quad * * \mathrm{p}<.01 ; \quad * * * \mathrm{p}<.001$

Since Affect, once entered, was more significant than Cognition, we analyzed the data again, this time reversing the entry order. The results are presented in Table 9.

Table 9: Hierarchical Regression Analysis with Affect entered before Cognition

\begin{tabular}{|l|l|l|l|l|l|}
\hline \multicolumn{1}{|c|}{ Step } & \multicolumn{1}{|c|}{$\begin{array}{c}\text { Independent } \\
\text { Variable(s) }\end{array}$} & Adj. $\mathbf{R}^{2}$ & $\begin{array}{c}\text { Change in } \\
\text { Adj. R }\end{array}$ & $\boldsymbol{\beta}$ & p \\
\hline 1 & Affect & .502 & .502 & .712 & $* * *$ \\
\hline 2 & Affect & .531 & .029 & .538 & $* * *$ \\
& Cognition & & & .251 & $* *$ \\
\hline
\end{tabular}

(Dependent variable $=$ Attitude $)$

$* \mathrm{p}<.05 ; \quad * * \mathrm{p}<.01 ; \quad * * * \mathrm{p}<.001$

As anticipated, both Affect and Cognition are significant and each adds to the predictive value of the model in accord with its order of entry into the model.

Based on these results, we state the following regarding the hypotheses:

- Hypothesis 1, "Attitude toward the behavior is significantly and positively related with intent to pursue IT certification within the next twelve months," is supported. Attitude was entered first into the regression equation $(\beta=.682, \mathrm{p}<.001)$.

- Hypothesis 2, "Subjective Norm is significantly and positively related with intent to pursue IT certification within the next twelve months," is supported. Attitude $(\beta=.588 ; \mathrm{p}<$ $.001)$ and Subjective Norm $(\beta=.226 ; p<.01)$ each contribute significantly to the equation. 
- Hypothesis 3, "Perceived Behavioral Control is significantly and positively related with intent to pursue IT certification within the next twelve months," is supported. Attitude ( $\beta$ $=.519 ; \mathrm{p}<.001)$, Subjective Norm $(\beta=.194 ; \mathrm{p}<.01)$, and Perceived Behavioral Control $(\beta=.161 ; \mathrm{p}<.05)$ are significant in the equation.

- Hypothesis 4, "Cognition is significantly and positively related with Attitude regarding pursuing IT certification within the next twelve months," is supported. Affect $(\beta=.538$; $\mathrm{p}<.001)$ and Cognition $(\beta=.251 ; \mathrm{p}<.01)$ each contributed significantly to the equation.

- Hypothesis 5, "Affect is significantly and positively related with Attitude regarding pursuing IT certification within the next twelve months," is supported. Affect was entered first into the regression equation $(\beta=.712 ; \mathrm{p}<.001)$.

\section{Discussion}

As expected, the three original TPB constructs are significant in predicting undergraduate information systems majors' intent to pursue IT certification within the next twelve months, with Attitude being the most influential. The second hierarchical regression showed that Affect influences Attitude far more than Cognition, thus providing support for the inclusion of Affect in future research using TPB and pointing to the need to consider emotions when investigating the reasons for which students make choices regarding the pursuit of IT certification or designing interventions to affect their behavior.

In summary, although all the relationships proposed by the theory were significant, Affect or emotion appears to be the most significant single influence on this decision for this group.

Previous research has indicated that employers tend to look favorably upon job applicants holding IT certification. The majority of students indicated in the survey that they would tend to do what these referent groups think they should do. Nevertheless, about one-third of the students surveyed provided a "neutral" response to the statements measuring whether they believe IT managers and hiring managers think they should pursue an IT certification. In the area of IT certification, it appears that there is a disconnect between what IT and hiring managers desire from job applicants and what students believe these managers look for in prospective employees.

We did not include time to prepare for or take certification exams in our survey because the matter did not come up in our initial interviews, but the open-ended responses to the survey suggest that we should include it in future work, as it would be a self-efficacy belief. "Time constraints are the biggest factor currently in my pursuing an IT certification," said one respondent.

It is ironic to read comments professing ignorance of testing centers and financial concessions for undergraduates when an academic department already offers reduced pricing on certification exams and loans certification materials to students at no charge. Although lack of money may prevent some students from pursuing certification, ignorance or lack of knowledge may exacerbate the issue.

One solution to this problem would be to have teachers remind students often of the resources that are available. Some students concur. "In the two years I have been in the [information systems] department," said one student, "this is the first time I have heard about IT certification...it would be nice to have someone mention it to students at some point." Another student advocated that IT certification be talked about more in classes and that students be "informed more on how to begin the process of studying for and then ultimately taking these exams and earning the certifications." 
Hunsinger \& Smith

"It would only make sense if more professors were more involved with this process in the [information systems] department," said another student, "actively advertising certifications related to their course. It would make it a lot easier if they were part of the exam process."

\section{Conclusion}

The findings of our study can be used to better understand the factors influencing undergraduate information systems majors to pursue IT certification. We found that Attitude, Subjective Norm, and Perceived Behavioral Control significantly influence Behavioral Intention. Our results point to Attitude as the most important influence on Behavioral Intention by this group and indicate that Affect, or emotion, is the most important influence on Attitude. We discovered a gap between what IT and hiring managers desire from job applicants, and what students believe these managers look for in prospective employees. About 1/3 of respondents rated as "neutral" the statements asking them whether they believe IT managers and hiring managers think they should pursue an IT certification. This was surprising given that these managers are ultimately responsible for delivering the benefits of IT certification. As well, little more than half the respondents indicated that they had the money and resources to pursue IT certification.

Student comments suggested that lack of time was an important impediment for them, an item that did not emerge from our initial interviews. Future work should include "the lack of time" as part of the Perceived Behavioral Control construct. This limiting factor did not come up in the preliminary interviews with students, but was mentioned in several of the online survey's openended responses. We suspect that the role of Perceived Behavioral Control will increase with the inclusion of the lack of time.

A number of students (26.4\%) indicated that they lack knowledge about certification options; they believe that faculty should play a more active role in informing them about certifications related to course content and the opportunities available to them through certification. Making students better aware of their certification options will help us close the gap between hiring managers' expectations and students' lack of knowledge concerning certification.

Our research was limited by its sample. Future work could examine and compare other geographical areas in the US and even examine students' perceptions of IT certification in other countries. Even though our sample size $(n=120)$ was adequate for the hierarchical analysis, a larger sample would allow us to use structural equation modeling to further explore the relationships among the constructs.

In the IT field, voluntary certification is an important means by which job applicants can indicate the skills they possess. Regardless of whether the skills needed for certification are developed through coursework or extracurricular activities, teachers and trainers who are interested in seeing their students fare well in the job market should encourage them to investigate becoming certified in their desired area of IS.

Our study found that Affect (how students FEEL about certification) is more influential on Attitude than Cognition (what students THINK about certification). Job and salary benefits are important to students; information about these benefits should obviously be presented to them. However, since our study discovered that Affect is more influential than Cognition, we also suggest emphasizing information that will appeal to students' emotions. We found that $81 \%$ of the students indicated that they would feel PROUD pursuing an IT certification. This could be compared to how doctoral students feel when pursuing a $\mathrm{PhD}$ or similar terminal degree. Students may possess additional confidence going onto the job market with the pride of holding an IT certification. Benefits of IT certification mentioned by employees in a previous trade study (Sosbe, Hollis, Summerfield, \& McLean, 2005) included several relating to Affect or emotions, including 
gaining greater confidence, earning prestige and recognition from colleagues, and being part of a community of certified professionals.

Although one might expect that logical, cognitive arguments would be the most effective way to encourage students to pursue certification, our results suggest that the promise of an emotional payoff would be more influential.

\section{References}

Ajzen, I. (1991). The Theory of Planned Behavior. Organizational Behavior and Human Decision Processes, 50, 179-211.

Ajzen, I. (2001). Nature and operation of attitudes. Annual Review of Psychology, 52, 27-58.

Ajzen, I. (2002, revised 2006) Constructing a TpB questionnaire: Conceptual and methodological considerations. Retrieved June 17, 2008 from http://wwwunix.oit.umass.edu/ aizen/pdf/tpb.measurement.pdf

Ajzen, I., \& Fishbein, M. (1980). Understanding attitudes and predicting social behavior. Englewood Cliffs, New Jersey: Prentice-Hall.

Ajzen, I., \& Fishbein, M. (2005). The influences of attitudes on behavior. In D. Albarracin, B. T. Johnson, \& M. P. Zanna (Eds.), Handbook of attitudes and attitude change: Basic principles (pp. 173-222). Mahwah, New Jersey: Erlbaum.

Ajzen, I., \& Madden, T. J. (1986). Prediction of goal-directed behavior: Attitudes, intentions, and perceived behavioral cntrol. Journal of Experimental Social Psychology, 22, 453-474.

Al-Rawi, A. Bouslama, F., \& Lansari, A. (2006). Preparing undergraduate students for IT certification. Issues in Informing Science and Information Technology, 3, 33-44. Retrieved from http://informingscience.org/proceedings/InSITE2006/IISITAIRa185.pdf

Al-Rawi, A., Lansari, A., \& Bouslama, F. (2005). A holistic approach to develop IS curricula: Focusing on accreditation and IT certification. Journal of Information Technology Education, 4, 307-327. Retrieved from http://jite.org/documents/Vol4/v4p307-327Al-Rawi73.pdf

Armitage, C. J., \& Conner, M. (2000). Efficacy of the theory of planned behavior: A meta-analytic review. Journal of Social Psychology, 471-499.

Bandura, A. (1977). Self-Efficacy: Toward a unifying theory of behavioral change. Psychological Review, $84,191-215$.

Brookshire, R. (2000). Information technology certification: Is this your mission? Information Technology, Learning, and Performance Journal, 18 (2), 1-2.

Burns, N., \& Grove, S. K. (2001). The practice of nursing research. Philadelphia: W.B. Saunders Co.

Cegielski, C. (2004). Who values technology certification? Communications of the ACM, 47 (10), 103105.

Cegielski, C., Rebman, C., \& Reithel, B. (2003). The value of certification: An empirical assessment of the perceptions of end-users of local area networks. Information Systems Journal, 13, 97-107.

Chau, P. Y., \& Hu, P. J.-H. (2001). Information technology acceptance by individual professionals: A model comparison approach. Decision Sciences, 32(4), 699-719.

Childs, K. (2002, February). Conquering the IT job market--Find the right job for you! Certification Magazine. Retrieved July 18, 2003, from http://www.certmag.com/issues/feb02/feature childs.cfm

Christian, J., \& Armitage, C. J. (2002). Attitudes and intentions of homeless people toward service provision in South Wales. British Journal of Social Psychology, 41(2), 219-231. 
Crites, S. L., Fabrigar, L. R., \& Petty, R. E. (1994). Measuring the affective and cognitive properties of attitudes: conceptual and methodological issues. Personality \& Social Psychology Bulletin, 20, 619634.

Davis, F. D. (1989). Perceived usefulness, perceived ease of use, and user acceptance of information technology. MIS Quarterly, 13(3), 318-339.

Davis, F. D., Bagozzi, R. P., \& Warshaw, P. R. (1989). User acceptance of computer technology: A comparison of two theoretical models. Management Science, 35(8), 982-1003.

Davis, L. E., Ajzen, I., Saunders, J., \& Williams, T. (2002). The decision of African American students to complete high school: An application of the theory of planned behavior. Journal of Educational Psychology, 94(4), 810-819.

Dohner, S. (2001). Industry research: The value of certification. Proceedings of the RESULTS 2001 Conference. Las Vegas, Nevada.

Domingo, M. (2007). Salary survey: Redmond's 12th annual IT salary survey. Microsoft Certified Professional Magazine: Online. Retrieved December 28, 2007, from http://mcpmag.com/salarysurveys/default.asp

Eagly, A. H., \& Chaiken, S. (1993). The psychology of attitudes. Forth Worth, Texas: Harcourt Brace Jovanovich College Publishers.

Fishbein, M., \& Ajzen, I. (1975). Belief, attitude, intention and behavior: An introduction to theory and research. Reading, Massachusetts: Addison-Wesley.

Flynn, T. (2002). Unlocking the Power of Certification - How to Develop Effective Certification Programs. Available at http://www.performetrics.biz/previewch1.html

Gabelhouse, G. (2001, December). Certification: Something of value. Certification Magazine , 3(12).

Gabelhouse, G. (2002, December). Certification, salaries \& the IT market. Certification Magazine , 4(12), pp. 26-34.

Garson, G. D. (n.d.). Statnotes: Topics in multivariate analysis. Testing of assumptions. Retrieved February 25, 2005, from http://www2.chass.ncsu.edu/garson/pa765/assumpt.htm

Haddock, G., \& Zanna, M.P. (1998). Assessing the impact of affective and cognitive information in predicting attitudes toward capital punishment. Law and Human Behavior, 22(3), 325-339.

Harrison, D. A., Mykytyn, P. P., \& Riemenschneider, C. K. (1997). Executive decisions about adoption of information technology in small business: Theory and empirical tests. Information Systems Research, $8(2), 171-195$.

Hitchcock, L. (2005). Industry certification: Value, validity, and a place for SoDIS. Inroads - The SIGCSE Bulletin, 37(4), 59-63.

Hitchcock, L. (2007). Industry certification and academic degrees: Complementary, or poles apart? SIGMIS-CPR '07, St. Louis, MO, 95-100.

Hunsinger, D. S., \& Smith, M. A. (2005). Predicting hiring managers' intentions to use IT certification in the selection process. Journal of Information Technology Management, 16(4), 1-18.

Ingram, K. L., Cope, J. G., Harju, B. L., \& Wuensch, K. L. (2000). Applying to graduate school: A test of the theory of planned behavior. Journal of Social Behavior and Personality, 15(2), 215-225.

ITAA. (2001). When can you start? Building better information technology skills and careers. Retrieved April 26, 2002, from http://www.itaa.org/workforce/studies/toc.pdf

Lavine, H. L., Thomsen, C. J., Zanna, M. P., \& Borgida, E. (1998). On the primacy of affect in the determination of attitudes and behavior: The moderating role of affective-cognitive ambivalence. Journal of Experimental Social Psychology, 34, 398-421. 
Manstead, A. S., \& Parker, D. (1995). Evaluating and extending the theory of planned behaviour. In W. Stroebe, \& M. Hewstone (Eds.), European Review of Social Psychology (pp. 69-95). Chichester, England: Wiley.

McCarthy, K. (2002). Salary surveys: Money matters. Microsoft Certified Professional Magazine: Online. Retrieved July 18, 2003, from http://mcpmag.com/salarysurveys/article.asp?EditorialsID=58

Morris, J. D., Wood, C., Geason, J. A., \& Kim, J. (2002). The power of affect: Predicting intention. Journal of Advertising Research, 42(3), 7-17.

Morris, M. G., \& Venkatesh, V. (2000). Age differences in technology adoption decisions: Implications for a changing workforce. Personnel Psychology, 53, 375-403.

Nunnally, J C. (1978). Psychometric theory (2 ${ }^{\text {nd }}$ ed.). New York: McGraw Hill.

Randall, M. \& Zirkle, C. (2005). Information technology student-based certification in formal education settings: Who benefits and what is needed. Journal of Information Technology Education, 4, 287-306. Retrieved from http://jite.org/documents/Vol4/v4p287-306Randall78.pdf

Ray, C. \& McCoy, R. (2000). Why certification in information systems? Information Technology, Learning, and Performance Journal, 18(1), 1-4.

Rowe, J. (2003, April). IT certifications: Lessons from other industries. Certification Magazine. Retrieved July 28, 2003, from http://www.certmag.com/articles/templates/cmag feature.asp?articleid=171

Santos, J. R. (1999). Cronbach's alpha: A tool for assessing the reliability of scales. Journal of Extension, $37(2)$.

Shaffhauser, D. (2002). Salary survey: second annual TCPmag.com Cisco salary survey. Retrieved June 18, 2003, from http://tcpmag.com/salarysurveys/article.asp?EditorialsID $=198$

Sheppard, B. H., Hartwick, J., \& Warshaw, P. R. (1988). The theory of reasoned action: A meta-analysis of past research with recommendations for modifications and future research. Journal of Consumer Research, 15, 325-343.

Simons, J., \& Carey, K. B. (1998). A structural analysis of attitudes toward alcohol and marijuana use. Personality \& Social Psychology Bulletin, 24(7), 727-736.

Sosbe, T. (2001, December). Certification training: Real results, real value. Certification Magazine, 3(12).

Sosbe, T., Hollis, E., Summerfield, B., \& McLean, C. (2005). CertMag's 2005 salary survey: Monitoring your net worth. Certification Magazine. Retrieved June 16, 2008 from http://www.certmag.com/images/CM1205_Figure5.htm

Stockburger, D. (1998, March). Multivariate statistics: Concepts, models, and applications by David Stockburger. Retrieved 12 28, 2007, from http://www.psychstat.missouristate.edu/multibook/mlt00.htm

Sutton, S. (1998). Predicting and explaining intentions and behavior: How well are we doing? Journal of Applied Social Psychology, 28(15), 1317-1338.

Tabachnick, B. G., \& Fidell, L. S. (2000). Using multivariate statistics (4th ed). New York: Harper \& Row.

Tittel, E. (2001). Certification essentials. Retrieved April 22, 2003, from http://www.leapit.com/html/cert essentials/toc.htm

Venkatesh, V. (2001). A Longitudinal investigation of personal computers in homes: Adoption determinants and Emerging Challenges. MIS Quarterly, 25(1), 71-102.

Verplanken, B., Hofsee, G., \& Janssen, H. J. (1998). Accessibility of affective vs. cognitive components of attitudes. European Journal of Social Psychology, 28, 23-35.

Weber, M. (1978). Economy and society: An outline of interpretive sociology. G. Ross, \& C. Wittich, (Eds.), Berkeley and Los Angeles, California: University of California Press. (Original work published in 1922.) 
Zeng, F. (2004). A new way to integrate computer technology certifications into computer information system programs. American Society for Engineering Education Annual Conference \& Exposition, Session 2558.

\section{Biographies}

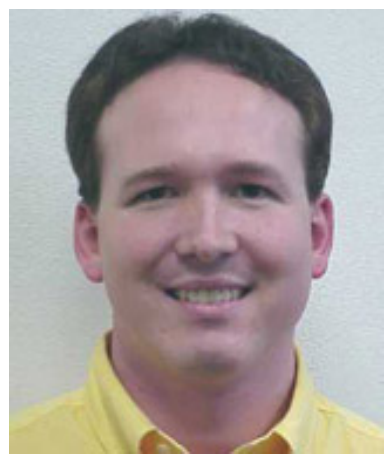

D. Scott Hunsinger is an Assistant Professor of Computer Information Systems in the Walker College of Business at Appalachian State University in Boone, North Carolina, USA. He holds a Ph.D. in Information Technology from The University of North Carolina at Charlotte. His research interests include IT certification, IT adoption, and group usage of technology. He has published articles in journals including Journal of Information Technology Management, International Journal of Computers, Systems and Signals, and Journal of Organizational and End User Computing.

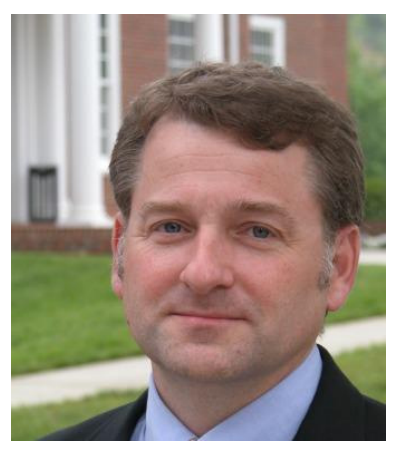

Michael Smith is an Associate Professor of Information Systems in the Phillips School of Business of High Point University in High Point, North Carolina, USA. He received the M.S.M. from Georgia Tech in 1993 and the Ph.D. in 1998. His research interests include the management of information systems and the effect of technology use on information-based industries. His research has appeared in journals including Information \& Management, Journal of Management Information Systems, European Journal of Operational Research, Journal of Information Technology Management, International Journal of Operations and Production Management, and Communications of the ACM. 